\title{
Diversity of antibiotic-producing Actinomycetes in mangrove forest of Torosiaje, Gorontalo, Indonesia
}

\author{
YULIANA RETNOWATI ${ }^{1.2 .}$, LANGKAH SEMBIRING ${ }^{3}$, SUKARTI MOELJOPAWIRO ${ }^{3}$, \\ TJUT SUGANDAWATY DJOHAN ${ }^{3}$, ENDANG SUTARININGSIH SOETARTO ${ }^{3, \vee \vee}$ \\ ${ }^{1}$ Graduate Study Program of Biology, Faculty of Biology, Universitas Gadjah Mada. J1. Teknika Selatan, Sleman 55281, Yogyakarta, Indonesia. \\ ${ }^{2}$ Department of Biology, Faculty of Mathematics and Natural Sciences, Universitas Negeri Gorontalo. J1. Jenderal Sudirman No. 6, Kota Gorontalo \\ 96128, Gorontalo, Indonesia. Tel.: +62-435-821125; Fax.: +62-435-821752. `email: yuliana_ri@yahoo.com \\ ${ }^{3}$ Faculty of Biology, Universitas Gadjah Mada. J1. Teknika Selatan, Sleman 55281, Yogyakarta, Indonesia. Tel./Fax.: +62-274-580839, \\ * email: annisah-endang@ugm.ac.id
}

Manuscript received: 14 May 2017. Revision accepted: 23 September 2017.

\begin{abstract}
Retnowati Y, Sembiring L, Moeljopawiro S, Djohan TS, Soetarto ES. 2017. Diversity of antibiotic-producing actinomycetes in mangrove forest of Torosiaje, Gorontalo, Indonesia. Biodiversitas 18: 1453-1461. Actinomycetes for antibiotic production have been studied at various extreme environments. Mangrove forest of Torosiaje in Gorontalo Province, Indonesia has unique geomorphological conditions where the forest is surrounded by karst ecosystem consisting of fringe and overwash types. Therefore, the objective of this study was to analyze the distribution and diversity of antibiotic-producing Actinomycetes in various rhizosphere including different locations and mangrove species. Samples of rhizosphere soil were collected in the depth of $0-10 \mathrm{~cm}$, which was then subjected to detailed physicochemical analysis. Actinomycetes were collected through heating pre-treatment $\left(60^{\circ} \mathrm{C}\right.$ for 15 min) followed by culturing in the Starch Casein Agar medium supplemented with cycloheximide and nystatin. The screening process of antibiotic-producing Actinomycetes was based on Agar block method against pathogenic microorganisms. Grouping of Actinomycetes was determined by ARDRA fingerprinting analysis. The diversity of Actinomycetes was analyzed based on sequencing of $16 \mathrm{~S}$ rDNA. The results showed that the distribution of Actinomycetes was found in overwash type, middle zone and upper zone of fringe type including rhizosphere of 7 species of mangrove. The highest population of Actinomycetes was found in rhizosphere of $R$. mucronata at the overwash type, and the lowest one found in rhizosphere of $R$. apiculata at the middle zone of fringe type. A total of 77 isolates amongst 167 isolate collection showed antibacterial activities. Forty seven representatives from 77 antibacterial-activities isolates were selected using ARDRA for partial characterization according to their phylogenetic diversity. Sequencing and analysis of 16S rDNA from selectedrepresentative isolates displayed the presence of members associated with Actinomycetes genera such as Streptomyces, Amycolatopsis, Saccharomonospora, and Nocardiopsis. The member of genus Streptomyces such as Streptomyces qinglanensis and Streptomyces champavatii were distributed across locations. Genus Saccharomonospora and Nocardiopsis were mostly found at the overwash type, while Amycolatopsis was found at the upper zone of fringe type.
\end{abstract}

Keywords: Actinomycetes, diversity, fringe, mangroves, overwash

\section{INTRODUCTION}

Actinomycetes are Gram-positive bacteria that produce bioactive compound (Amrita et al. 2012). $70-80 \%$ of bioactive compounds are produced by Actinomycetes (Kanna et al. 2011), especially Streptomyces (Berdy 2005; Chaudary et al. 2013), and a part of bioactive compounds is produced by rare-Actinomycetes (Berdy 2005). The exploration of Actinomycetes that produce bioactive compounds has been focused on the extreme environment due to the rediscovery of bioactive compounds from terrestrial environment (Nolan and Cross 1988; Mangamuri et al. 2014). Mangrove forest is one of interesting ecosystems to explore Actinomycetes (Santhi et al. 2010; Baskaran et al. 2011; Khanna et al. 2011; Naikpatil and Rathod 2011; Ravikumar et al. 2011; Mangamuri et al. 2012; Mangamuri et al. 2014).

Mangrove ecosystem is a habitat of various of Actinomycetes. The Actinomycetes of mangrove ecosystem produce 122 bioactive compounds, where 73 of them have been identified as new kinds of bioactive compounds, and 49 compounds have not been identified, yet $(\mathrm{Xu}$ et al. 2014). The bioactive compounds from mangrove Actinomycetes demonstrate antibacterial activity (Sharma et al. 2011; Hunadanamra et al. 2013; Das et al. 2014; Phongsopitanum et al. 2014), anti fungal activity (Suthindiran and Kannabiran 2010; Sharma et al. 2011; Phongsopitanum et al. 2014; Das et al. 2014), and anti viral activity (Waksman 1984) and anti cancer activity (Hong et al. 2009; Suthindiran and Kannabiran 2010; BecerrilEspinosa et al. 2012; Ravikumar et al. 2012; Anupa et al. 2013; Xu et al. 2014).

Actinomycetes producing bioactive compounds in mangrove ecosystem are distributed on rhizosphere and non rhizosphere (Xiao 2009; Ravikumar et al. 2011), which rarely live as endophytics on stems and leaves of mangrove (Ravikumar et al. 2011; Gayathri and Muralikrishman 2013; Govindasamy and Franco 2013). The number of Actinomycetes population in rhizosphere are more than those in non rhizosphere. The various number of Actinomycetes is also depended on types of mangrove (Balagurunathan et al. 2010; Ravikumar et al. 2011; 
Ramirez-Elias et al. 2014).

Mangrove ecosystem of Torosiaje is karst mangrove ecosystem including two types of forest, i.e., fringe and overwash types. The fringe type is divided into two zones, i.e. middle and upper zone. The middle zone was dominated by Rhizophora apiculata and Bruguiera gymnorrhiza while the upper zone consists of Sonneratia alba, Avicennia marina, Xylocarpus sp., and Ceriops tagal. The overwash type consists of Rhizophora mucronata and Bruguiera gymnorrhiza (Katili et al. 2014). Based on the uniqueness of Torosiaje mangrove ecosystem and some other important aspects; however, the diversity and distribution of Actinomycetes in this location had not been comprehensively explored, yet. Therefore, the objective of this study was to analyze the diversity and distribution of antibiotic-producing Actinomycetes in rhizosphere of various species mangrove located at mangrove ecosystem of Torosiaje, Gorontalo, Indonesia.

\section{MATERIALS AND METHODS}

Study area and sampling of soil rhizospheres. This study was conducted from April 2016 to April 2017. Samples of mangrove rhizospheres soil were collected from mangrove forest at Torosiaje, Pohuwato District, Gorontalo Province, Indonesia (Figure 1). The total of eight soil samples was collected from 3 different location i.e overwash type, middle zone and upper zone of fringe type, including 7 species of mangrove rhizospheres (Rhizophora mucronata, Rhizophora apiculata, Bruguiera gymnorrhiza, Avicennia marina, Xylocarpus sp., Ceriops tagal and Sonneratia alba). Sampling sites were located at 3 different coordinates i.e N. $00^{\circ} .28^{\prime} .21,9^{\prime \prime} ; \mathrm{E} .121^{\circ} .26^{\prime} .55,7^{\prime \prime} ; \quad \mathrm{N}$ $00^{\circ} .28^{\prime} .50,5^{\prime}$; E. $121^{\circ} .27^{\prime} .56,8^{\prime \prime}$ and N. $00^{\circ} .28^{\prime} .47,2$; E. $121^{\circ} .27^{\prime} .56,2^{\prime}$. Soil samples were collected on the depth of $0-10 \mathrm{~cm}$ by modified soil core with 4 replication.

Soil physicochemical characteristic analysis. The physicochemical analysis of soil samples (salinity, soil texture, soil $\mathrm{pH}, \mathrm{C}$-organic, total-N, $\mathrm{N}-\mathrm{NO}_{3}, \mathrm{Fe}, \mathrm{Mn}, \mathrm{Zn}$, $\mathrm{Cu}$, phosphor, $\mathrm{K}_{2} \mathrm{O}$ and total $\mathrm{S}$ ) was conducted at Soil Chemical laboratory, Faculty of Agriculture, Gadjah Mada University, Yogyakarta, Indonesia.

The isolation of actinomycete isolates. The initial treatment of rhizosphere soil samples was based on dry wet method on $60^{\circ} \mathrm{C}$ for 15 minutes in combination of sea water and aquadest (1: $1 \mathrm{v} / \mathrm{v})$ (Mangamuri et al. 2012). Soil suspension was serial-diluted up to $10^{-6}$. Soil suspension as much as $100 \mu \mathrm{L}$ was inoculated in Starch Casein Agar (SCA) medium supplemented by $25 \mu \mathrm{g} / \mathrm{mL}$ of cycloheximide and $25 \mu \mathrm{g} / \mathrm{mL}$ of nystatin (Baskaran et al. 2011). Then incubated on $28 \pm 2{ }^{\circ} \mathrm{C}$ for $10-28$ days. Colony Forming Unit (CFU) was calculated and isolated in slant ISP 2 medium.

Screening of actinomycete isolates for potential antibiotics production. The screening of Actinomycetes for potential antibiotics production was based on Agar Block Method. The medium Muller Hinton agar got 5 holes and each hole was $5 \mathrm{~mm}$ diameters. After 28 days of age, actinomycete isolates cultured on ISP2 medium were then clipped around $5 \mathrm{~mm}$ diameters and moved to the holes. The Actinomycetes were incubated on $28^{\circ} \mathrm{C} \pm 2$ for 3-7 days. The cell mass of microorganisms test (Escherichia coli, Staphylococcus aureus and Bacillus subtilis) on Nutrient Broth medium was equated by spectrophotometry on OD 0,6 . Afterward, $300 \mu \mathrm{L}$ of microorganisms test was inoculated in the around of actinomycete growing by surface plate method, then incubated on $37^{\circ} \mathrm{C}$ for $2 \times 24$ hours.

Extraction of genomic DNA. The spores of actinomycete isolates were suspended in aquadest. The suspension of spore was inoculated in $20 \mathrm{~mL}$ of ISP2 broth, then incubated in shaker incubator at $150 \mathrm{rpm}$ for 4 to 7 days. Cell pellet in $20 \mathrm{~mL}$ of ISP2 broth was separated by centrifugation at $13.000 \mathrm{rpm}$ for $5 \mathrm{~min}$. The cell pellet was added with $20 \mathrm{mg}$ of glass bead and $1 \mathrm{~mL}$ of buffer lysis (100mM Tris $\mathrm{HCl} \mathrm{pH} \mathrm{8,} 50 \mathrm{mM}$ EDTA pH 8, 2\% SDS and $100 \mathrm{mM} \mathrm{NaCl}$ ) then shaken out vigorously by vortex for 2 min. Proteinase K $(20 \mathrm{mg} / \mathrm{mL})$ as much as $10 \mu \mathrm{L}$ was added then shaken out vigorously for $30 \mathrm{~min}$. Then $60 \mu \mathrm{L}$ of lysozyme $(100 \mathrm{mg} / \mathrm{mL})$ was added and incubated on $55^{\circ} \mathrm{C}$ for $30 \mathrm{~min}$ in water bath. The suspension was centrifugated at $13.000 \mathrm{rpm}$ for $5 \mathrm{~min}$, then cell pellet was discarded and the supernatant was resuspended by phenol $(1: 1 \mathrm{v} / \mathrm{v})$. The suspension of supernatant and phenol were shaken vigorously for 30 minutes, then centrifugated on $13.000 \mathrm{rpm}$ for $10 \mathrm{~min}$. The top layer was moved to new microtube and added by cold chloroform (1: $1 \mathrm{v} / \mathrm{v})$, then shaken out slowly for 20 minutes. Then they were centrifugated on $13000 \mathrm{rpm}$ for 10 minutes. The top layer was moved to new microtube and added with cold absolute ethanol $(1: 1 \mathrm{v} / \mathrm{v})$, and saved on $-80^{\circ} \mathrm{C}$ for 2 hours or $-20^{\circ} \mathrm{C}$ for overnight. The DNA genome pellet was separated by centrifugation at $13000 \mathrm{rpm}$ for 10 minutes, cleaned up with $70 \%$ cold ethanol then dried for 2 hours. The DNA genome was suspended in $50 \mu \mathrm{L}$ of TE $(\mathrm{pH}$ 8). The suspension of DNA genome was added by $3 \mu \mathrm{L}$ of RNAase $(10 \mu \mathrm{g} / \mathrm{mL})$ and incubated on $37^{\circ} \mathrm{C}$ for 1 hour in water bath. The genomic DNA was applied or saved on $-20^{\circ} \mathrm{C}$. The genomic DNA were examined by $2 \%$ agarose gel electrophoresis. The gels were stained by syber and visualized under UV transilluminator (Magarvey et al. 2004).

Amplification of 16S rDNA. The 16S rDNA was amplified from genomic DNA samples using eubacterial universal primers $27 \quad \mathrm{~F} \quad$ (5'AGAGTTTGATCCTGGCTCAG-3') and 1492R (5'TACGGCTACCTTGTTACGACTT-3'). The amplification was carried out in $25 \mu \mathrm{L}$ volume by using $1 \mu \mathrm{L}$ of genomic DNA as template with $12.5 \mu \mathrm{L}$ GoTaq (R) Green Master Mix [buffer reaction, deoxynucleotide triphosphate (dNTPs), Taq DNA polymerase, and $\left.\mathrm{MgCl}_{2}\right], 9.5 \mu \mathrm{L}$ $\mathrm{dH} 2 \mathrm{O}$, and $1 \mu \mathrm{L}$ universal primer $27 \mathrm{~F}$ and $1 \mu \mathrm{L}$ 1492R. The thermal cycling conditions were as follows: initial denaturation at $96^{\circ} \mathrm{C}$ for $5 \mathrm{~min} ; 29$ cycles at $95^{\circ} \mathrm{C}$ for 1 $\min , 54^{\circ} \mathrm{C}$ for $1 \mathrm{~min}, 72^{\circ} \mathrm{C}$ for $2 \mathrm{~min}$ and post-extension at $72^{\circ} \mathrm{C}$ for $10 \mathrm{~min}$. The amplification reaction was performed by Bio-Rad thermal cycler (MyCycler, Bio-Rad, USA) and the amplified products were examined by $2 \%$ agarose gel electrophoresis (Mangamuri et al. 2012). 

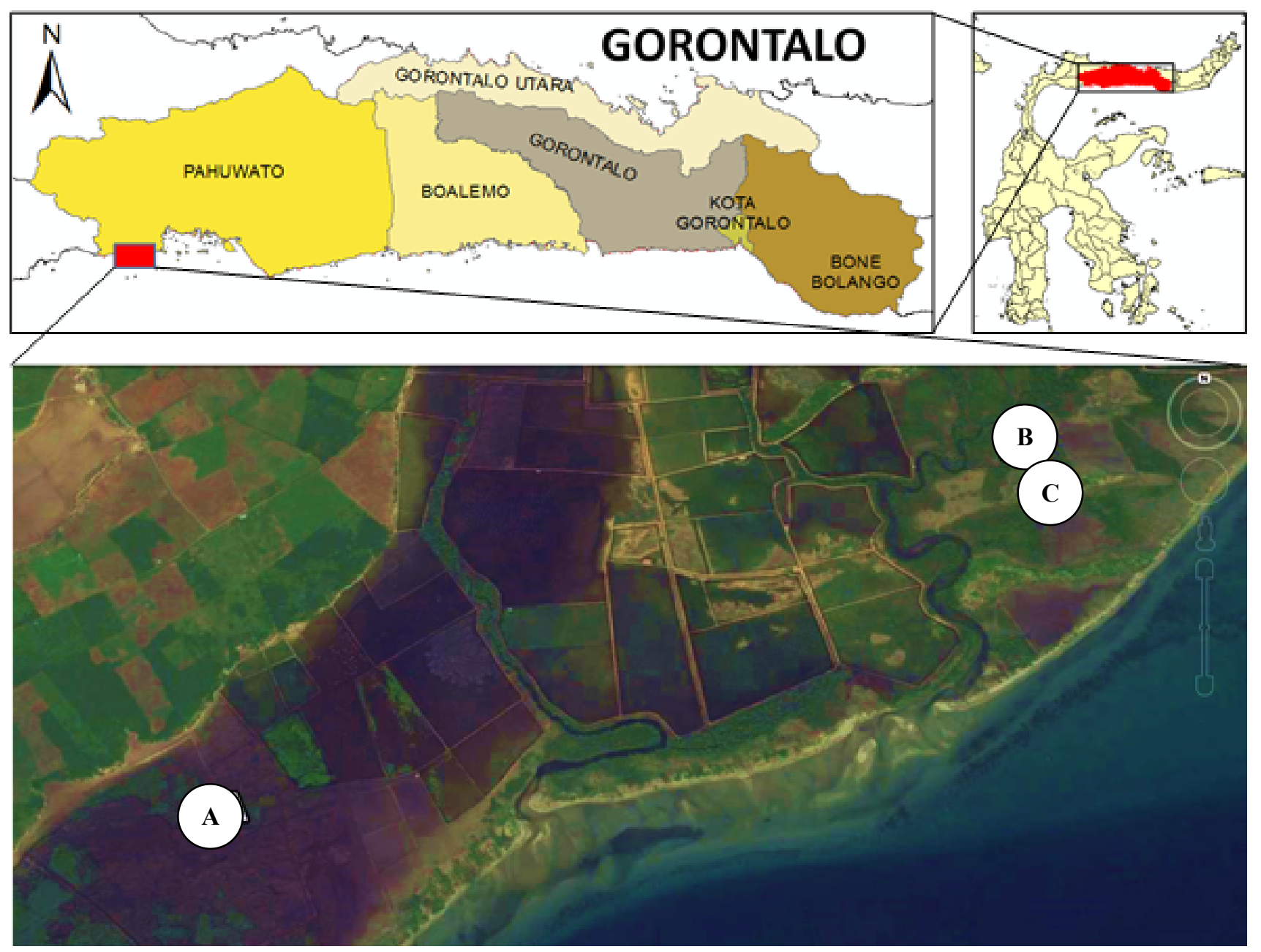

Figure 1. Location of mangrove forest of Torosiaje, Gorontalo, Indonesia. The alphabet A, B and C indicating the sampling site of mangroves soil rhizosphere at different mangrove forest type. A. overwash type (N. $\left.00^{\circ} .28^{\prime} .21,9^{\prime \prime} ; \mathrm{E} .121^{\circ} .26^{\prime} .55,7^{\prime \prime}\right)$, B. middle zone of fringe type (N. $00^{\circ} .28^{\prime} .50,5^{\prime \prime}$; E. $\left.121^{\circ} .27^{\prime} .56,8^{\prime \prime}\right)$, and C. upper zone of fringe type (N. $00^{\circ} .28^{\prime} .47,2$; E. $\left.121^{\circ} .27^{\prime} .56,2^{\prime \prime}\right)$

Amplified ribosomal DNA restriction analysis (ARDRA). To identify the number of polymorphic groups and to select representative strains among the actinomycete isolates, aliquots of purified $16 \mathrm{~S}$ rDNA amplicons were subjected to amplified ribosomal DNA restriction analysis. The purified PCR products were digested separately with HaeIII and MspI, in $10 \mu \mathrm{L}$ reaction volume by using manufacture's recommended buffer and temperature. The digested restriction fragments were electrophorezed in $2 \%$ agarose gels using TE buffer. The gels were stained with syber and visualized under UV transilluminator. Strong and clear bands were scored in a binary data used for similarity and clustering analysis in numerical taxonomy analysis program package, MVSV Plus (Multivariate Statistical Package) Version 3.1A. Similarities among the isolates were calculated by Jaccard's coefficient, and the dendrogram was constructed using UPGMA (Unweighted Pair Group Method with Arithmetic Averages) method (Jose and Jebakumar 2012). If the strains formed a cluster defined at the $72 \%$ similarity level, they would be assigned to a single species (Meng Yuan et al. 2014)

16S rDNA sequencing and phylogenetic analysis. The PCR amplicons of 47 actinomycete isolates with representative ARDRA profiles were purified by using PCR product purification spin kit (BigDye ${ }^{\circledR}$ Terminator v3.1, USA) and sequenced by ABI PRISM 3730xl Genetic Analyzer develop by Applied Biosystems using same primary set as used in PCR amplification. All the sequences obtained from sequencing phase were analyzed and edited by using BioEdit soft-ware (Jose and Jebakumar 2012). Initially, all the $16 \mathrm{~S}$ rDNA sequences were compared to sequences in GenBank by using the online service of Basic Local Alignment Search Tool to determine the approximate phylogenetic position. Sequences were aligned by using ClustalW with representative actinomycete $16 \mathrm{~S}$ rDNA sequences, and a phylogenetic tree was constructed by using the Molecular Evolutionary Genetics Analysis (MEGA) software, version 6.06 (Yuan et al. 2014). 


\section{RESULTS AND DISCUSSION}

\section{Physico-chemical characteristics of soil, population and distribution of Actinomycetes}

Mangrove forest ecosystem is a habitat for various types of tolerant microorganisms to an extreme environmental conditions. Mangrove forest ecosystems are rich in organic, nitrogen and sulfur materials that required for the grow of microorganisms (Malek et al. 2014). Mangrove ecosystem of Torosiaje, Gorontalo consist of two type mangrove forest i.e., overwash type and fringe type. Fringe type divided into 2 zone i.e., middle zone and upper zone. Each of mangrove forest type and zone were show the specific physicochemical characters. The sediment salinity level was in range of 23,1 - 31,3 ppt. The physico-chemical characteristics of soil samples collected from overwash mangrove, middle and upper zone of fringe mangrove at mangrove forest of Torosiaje, Gorontalo were studied using standard protocols and summarized in Table 1. Several parameters, such as $\mathrm{pH}$, salinity of soil, soil texture, macroelements and microelements have been measured. The results show that there were differences across all measurable characters in all three locations. Overwash type mangroves forest is washed periodically by tides of sea water so that it affects to the physicochemical character of the soil to be quite extreme, including salinity and high level of $\mathrm{Fe}$, while the organic-C content was relatively low. Middle zone and upper zone in fringe type mangrove forests were shown the differences physicochemical characters amongst both of them. The upper zone tends to be at least exposed by sea tides was shown sandy soil conditions with low salinity and neutral $\mathrm{pH}$.

The physicochemical character of the 3 sampling sites were responded by actinomycete as one of the members of the mangrove ecosystem. The responses of actinomycete were indicated by the various number of population in the three locations. The highest population of Actinomycetes was found on overwash type, and the lowest one was found on middle zone of fringe type (Table 2). The periodically tides of overwash type is causes a continuously flow of macro-element and micro-element that supporting the growth of soil microorganisms. Otherwise, the geographical condition of the sloping fringe mangrove forest causes the middle zone is more exposed by the tides than the upper zone. This condition might cause the nutrient in the middle zone was more transported out of the zone.

Actinomycetes exploration at mangrove forest of Torosiaje is more emphasized on rhizosphere soil samples of 7 types mangroves at the depth of $0-10 \mathrm{~cm}$. Nevin et al. (2000) and Mangamuri et al. (2011) claimed that the most Actinomycetes population were found in mangrove rhizosphere at the depth of 0-20 cm and apparently varied in each species of mangroves. The high population of Actinomycetes in the rhizosphere was due to the root exudation activities. That activity provided the space for actinomycete colonization and depended on the availability of amino acids and high concentrations of sugars and low concentrations of tannin content in rhizosphere (Atlas and Barta 1998; Badri and Vivanco 2009; Mangamuri et al. 2011). Mangamuri et al. (2011) also reported that the
Table 1. Physico-chemical characteristic of soil samples from overwash type, middle zone and upper zone of fringe type at mangrove forest of Torosiaje, Gorontalo, Indonesia

\begin{tabular}{|c|c|c|c|}
\hline \multirow[b]{2}{*}{$\begin{array}{l}\text { Physicochemical } \\
\text { characters of soil }\end{array}$} & \multicolumn{2}{|c|}{ Fringe type } & \multirow[b]{2}{*}{$\begin{array}{c}\text { Overwash } \\
\text { type }\end{array}$} \\
\hline & $\begin{array}{c}\text { middle } \\
\text { zone }\end{array}$ & $\begin{array}{l}\text { Upper } \\
\text { zone }\end{array}$ & \\
\hline Salinity (ppt) & 26.56 & 23.17 & 31.3 \\
\hline $\mathrm{pH}$ & 3.16 & 7.46 & 6.04 \\
\hline \multicolumn{4}{|l|}{ Soil texture: } \\
\hline Sand (\%) & 62 & 84 & 62 \\
\hline Dust (\%) & 31 & 10 & 26 \\
\hline Clay $(\%)$ & 7 & 6 & 12 \\
\hline C-organic (\%) & 12.63 & 23.33 & 2.18 \\
\hline $\mathrm{N}(\mathrm{ppm})$ & 102.94 & 246.65 & 610.40 \\
\hline Total-S (\%) & 0.38 & 0.20 & 0.43 \\
\hline $\mathrm{N}-\mathrm{NO}_{3}(\mathrm{ppm})$ & 24.09 & 66.44 & 62.31 \\
\hline $\mathrm{P}_{2} \mathrm{O}_{5}(\mathrm{ppm})$ & 63.33 & 21.31 & 3.09 \\
\hline $\mathrm{K}(\mathrm{me} / 100 \mathrm{~g})$ & 1.74 & 3.59 & 1.23 \\
\hline $\mathrm{Fe}(\mathrm{ppm})$ & 427.69 & 120.09 & 441.24 \\
\hline $\mathrm{Mn}(\mathrm{ppm})$ & 4.76 & 4.04 & 8.08 \\
\hline $\mathrm{Zn}(\mathrm{ppm})$ & 4.31 & 0.70 & 11.03 \\
\hline $\mathrm{Cu}(\mathrm{ppm})$ & 0.37 & 0.76 & 1.07 \\
\hline
\end{tabular}

Table 2. Population of Actinomycetes at 7 types mangrove rhizosphere

\begin{tabular}{lllc}
\hline $\begin{array}{c}\text { Mangrove } \\
\text { forest } \\
\text { type }\end{array}$ & Zone & Mangrove type & $\begin{array}{c}\text { Actinomycete } \\
\text { population } \\
\text { (CFU/g) }\end{array}$ \\
\hline Overwash & - & R. mucronata & $23,5 \times 10^{6}$ \\
& Total on overwash & $78,4 \times 10^{3}$ \\
Fringe & Middle & R. apiculata & $11,8 \times 10^{6}$ \\
& & B. gymnorhiza & $3,5 \times 10^{1}$ \\
& Sub total & S. alba & $10,1 \times 10^{3}$ \\
& Upper & A. marina & $30,7 \times 10^{2}$ \\
& & Xylocarpus & $34 \times 10^{1}$ \\
& & C. tagal & $33,6 \times 10^{3}$ \\
& & & $18,3 \times 10^{2}$ \\
& Sub total & $96,6 \times 10^{2}$ \\
& Total on fringe & $73,4 \times 10^{2}$ \\
\hline
\end{tabular}

important nutrients such as nitrogen and potassium were found to be highest in the soil depths of $0-10 \mathrm{~cm}$.

The isolation of actinomycete from mangrove rhizosphere using Starch Casein Agar medium supplemented with cycloheximide and nystatin was succeeded obtaining 167 actinomycete isolates. The type of mangrove vegetation affected the distribution and population of actinomycete (Balagurunathan et al. 2010; Ramirez-Elias et al. 2014; Ravikumar et al. 2011; Ravikumar et al. 2012). The result of study show that the number of actinomycete isolate was varied in the 7 types of mangrove rhizosphere (Figure 2). The highest number of isolate was found at $R$. mucronata rhizosphere and the lowest one at $R$. apiculata rhizosphere. This is probably due to the rhizospheres effect as a result of root exudation activity. The root exudates contains various compounds including amino acids, organic acids, sugars, phenols, 
tannins, alkaloids and various secondary metabolites (Atlas and Barta 1998; Walker et al. 2003). Exudation activities of various compounds in plant roots can regulate the soil microbial community by mediating soil-microbial root interactions, altering soil chemical physical properties and inhibiting the growth of plant competitors (Badri and Vivanco 2009). Each of mangrove species was produce a specific kind of root exudates. The adult of Avicennia marina is produce root exudates with different levels of glucose and fructose composition (Lie et al. 2014) and root exudates of Bruguiera gymnorrhiza contain of aminopyrine, palmitic acid, stearic acid, di-n-propyl-ether, and 2.5-angidroglunonic (Kumar et al. 2009).

\section{Screening of antibiotic-producing Actinomycetes based on agar block method}

Mangrove forests are interesting ecosystems for the discovery of antibiotic-producing Actinomycetes (Santhi et al. 2010; Baskaran et al. 2011; Khanna et al. 2011; Naikpatil and Rathod 2011; Ravikumar et al. 2011; Mangamuri et al. 2012; Mangamuri et al. 2014). The extreme conditions of mangrove environment are expected to stimulate the actinomycete to produce antibiotics with specific character (Basilio et al. 2003). The bioactive compound were shown the activity as antibacterial, antifungal, antiviral and anticancer (Suthindhiran et al. 2010; Ravikumar et al. 2011; Amrita et al. 2012; Doroghazi and Metcalf 2013; Zotchev 2014). This study proves that amongst 167 actinomycete isolates, there were 77 actinomycete isolates that show the antibacterial activity against pathogenic bacteria. The highest number of antibiotic-producing actinomycete isolates was found at rhizosphere of $R$. mucronata in overwash type, and the lowest one at rhizosphere of $C$. tagal in upper zone of fringe type (Figure 3). While the high ability of actinomycete isolates to against pathogenic microbes was found in rhizosphere of A. marina and Xylocarpus sp. at upper zone of fringe type. That was shown that mangrove forest of Torosiaje, Gorontalo was potential to exploration antibiotic-producing Actinomycetes.

Amplification of 16S rDNA and ARDRA. PCR amplification of the $16 \mathrm{~S}$ rDNA using a set of universal eubacterial specific primers: $27 \mathrm{~F}$ and $1492 \mathrm{R}$ yielded a single amplicon of $\sim 1500$ bp for 77 the antibioticproducing actinomycete isolates. The amplicons of $16 \mathrm{~S}$ rDNA were used to Amplified Ribosomal DNA Restriction Analysis (ARDRA) with restriction enzymes endonuclease HaeIII and MspI. Digestion of these amplicons with HaeIII were generated almost similar profile for several of isolates. Whereas, when amplicons were digested by restriction enzyme $M s p I$, different number of fragments were produced about 5 to 9 fragments with varied sizes about 30 to $900 \mathrm{bp}$ for different isolates.

The ARDRA pattern was used for dendrogram construction using UPGMA and Jaccard's coefficient algorithms (Figure 4). The 77 of antibiotic-producing actinomycete isolates were divided into 47 groups in a dendrogram inferred from ARDRA pattern obtained from $M s p$ I restriction enzymes. The groups consisted of 1 to 5 actinomycete isolates. The groups formed on the dendrogram provide information about the presence of the same species found in different location and different kinds of mangrove. If the isolates formed a group/cluster defined at the $72 \%$ similarity level, they would be assigned to a single species (Meng Yuan et al. 2014).

Figure 2. The number of Actinomycete isolates in 7 types of mangrove rhizosphere at mangrove forest of Torosiaje Gorontalo, Indonesia. O. Overwash; FM. Fringe/middle zone; FU. Fringe/upper zone

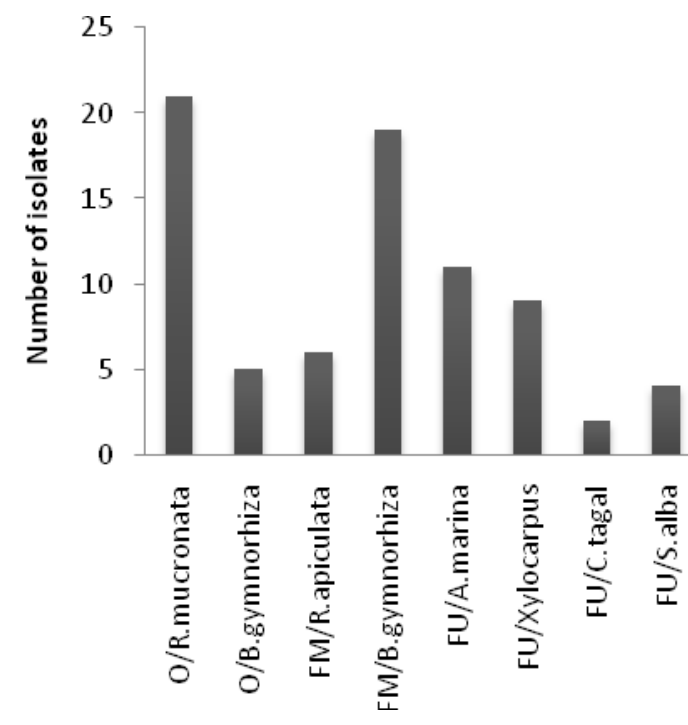

Figure 3. The number of antibiotic-producing Actinomycete isolates at 7 kind of mangrove rhizosphere. O. Overwash; FM. Fringe/middle zone; FU. Fringe/upper zone

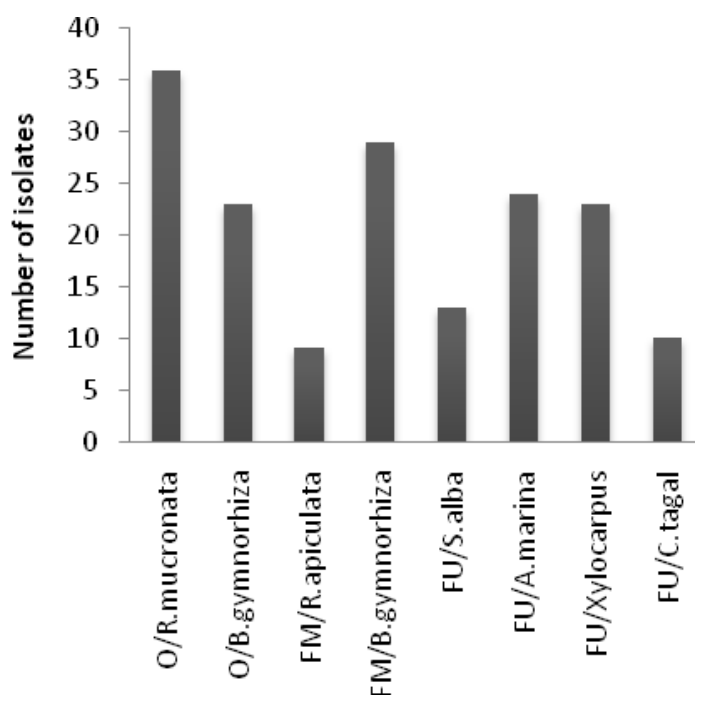


Actinomycetes community composition and phylogenetic analysis. The $16 \mathrm{~S}$ rDNA of 47 representative isolates that belong to different clusters established by ARDRA was sequenced and used to determine the diversity of isolates. Based on similar criteria of $98 \%$ at the 16S rRNA gene, the 47 isolates were sorted into 6 phylotypes, belong to 4 different genera. The four genera were Streptomyces, Saccharomonospora, Nocardiopsis and Amycolatopsis (Figure 5). The most abundant group of isolates was affiliated with the genus Streptomyces, represented by four ribotypes accounting for $95 \%$ of the total actinomycete population. The ribotypes ORm2-a was closely related to type strain Streptomyces qinglanensis (GenBank: NR 109303.1) with 99.9\% sequence similarity, representing $8 \overline{3} \%$ of total isolates. The other ribotypes of Streptomyces, OBg1-3 (representing 5\% of isolates) and FMRa1-1 (representing 7\% of all isolates) were closely related to type strain Streptomyces sanyensis (GenBank: NR_116599.1) with $99 \%$ sequence similarity and Streptomyces champavatii (GenBank: NR_115669.1) with $97 \%$ sequence similarity, respectively. The second most dominant group in the isolates was the genera Nocardiopsis, representing $3 \%$ of total actinomycete isolates. Ribotype ORm2-f was closely related to type strain Nocardiopsis lucentensis (GenBank: NR_026342.1) with $99 \%$ of sequence similarity. Ribotype FUXy2-d and OBg4-e representing $1 \%$ of total actinomycete isolates, respectively. Ribotype FUXy2-d was closely related to type strain Amycolatopsis sacchari (GenBank: NR_112696.1) with $94 \%$ of sequence similarity. While, ribotype OBg4-e was closely related to type strain Saccharomonospora amisosensis (GenBank: NR_109529.1) with 97\% of sequence similarity.

The four genus of antibiotic-producing Actinomycetes were distributed at overwash type, middle zone and upper zone of fringe type of mangrove forest of Torosiaje, Gorontalo (Figure 6). Several studies have been conducted in various mangrove ecosystems around the world and managed to discover various new types of Actinomycetes from rhizosphere of mangrove, non rhizosphere and endophytes in stems, roots and leaf of mangrove (Mangamuri et al. 2011). Several types of members of the Actinomycetes group were found in the mangrove ecosystem. They were Streptomyces avicenniae sp. nov., (Xiao et al. 2009), Streptomyces qinglanensis sp. nov., (Hu et al. 2012). The result of study show that genus Streptomyces, especially Streptomyces qinglanensis was the most dominant species and distributed across locations. Several studies were reported that the Actinomycetes community at mangrove ecosystem dominated by Streptomyces (Kannan and Vincent 2011; Mangamuri et al. 2014; Malek et al. 2014). Streptomyces qinglanensis was established by $\mathrm{Hu}$ et al. (2012) as a novel species of the genus Streptomyces that isolated from mangrove sediment at Qinglan Harbor, Wenchang, Hainan, China.

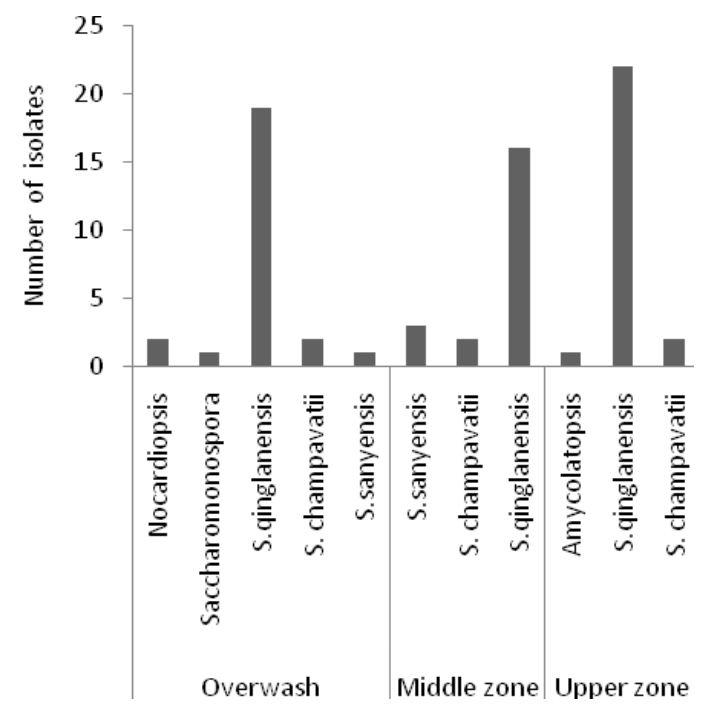

Figure 6. Distribution genus member of antibiotic-producing Actinomycetes at different location on mangrove forest of Torosiaje, Gorontalo

The genus Nocardiopsis and Saccharomonospora were specific found at overwash type, while genus Amycolatopsis at upper zone of fringe type. The genus Saccharomonospora which belongs to the family Pseudonocardiaceae was established by Nonomura and Ohara (1971). Saccharomonospora amisosensis was established by Veyisoglu et al. (2013) as novel species isolated from deep marine sediment at southern Black Sea coast of Turkey. Several members of genus Saccharomonospora were isolated from an extreme environments. Nocardiopsis strains are distributed ubiquitously in the environment. They are frequently isolated from habitats with moderate to high salt concentration such as saline soil or marine sediment (Sabry et al. 2004) and slattern (Chun et al. 2000).

In conclusion, distribution and diversity of Actinomycetes were explored from mangrove ecosystem at Torosiaje, Pohuwato District, Gorontalo Province, Indonesia. 167 actinomycete isolates were isolated from 7 types of mangrove rhizosphere. They were distributed at overwash mangrove, middle and upper zone of fringe mangrove. Among 167 actinomycete isolates, there were 77 actinomycete isolates shown antibacterial activity against pathogenic bacteria. The isolates which shown high antibacterial activity were found at rhizosphere of $A$. marina and Xylocarpus sp. The Actinomycetes that produce antibiotics were assigned to four genera i.e Streptomyces, Saccharomonospora, Amycolatopsis and Nocardiopsis on the basis of their16S rDNA sequences. This is the first step towards better understanding of actinomycete from mangrove ecosystem at Torosiaje, Gorontalo. 


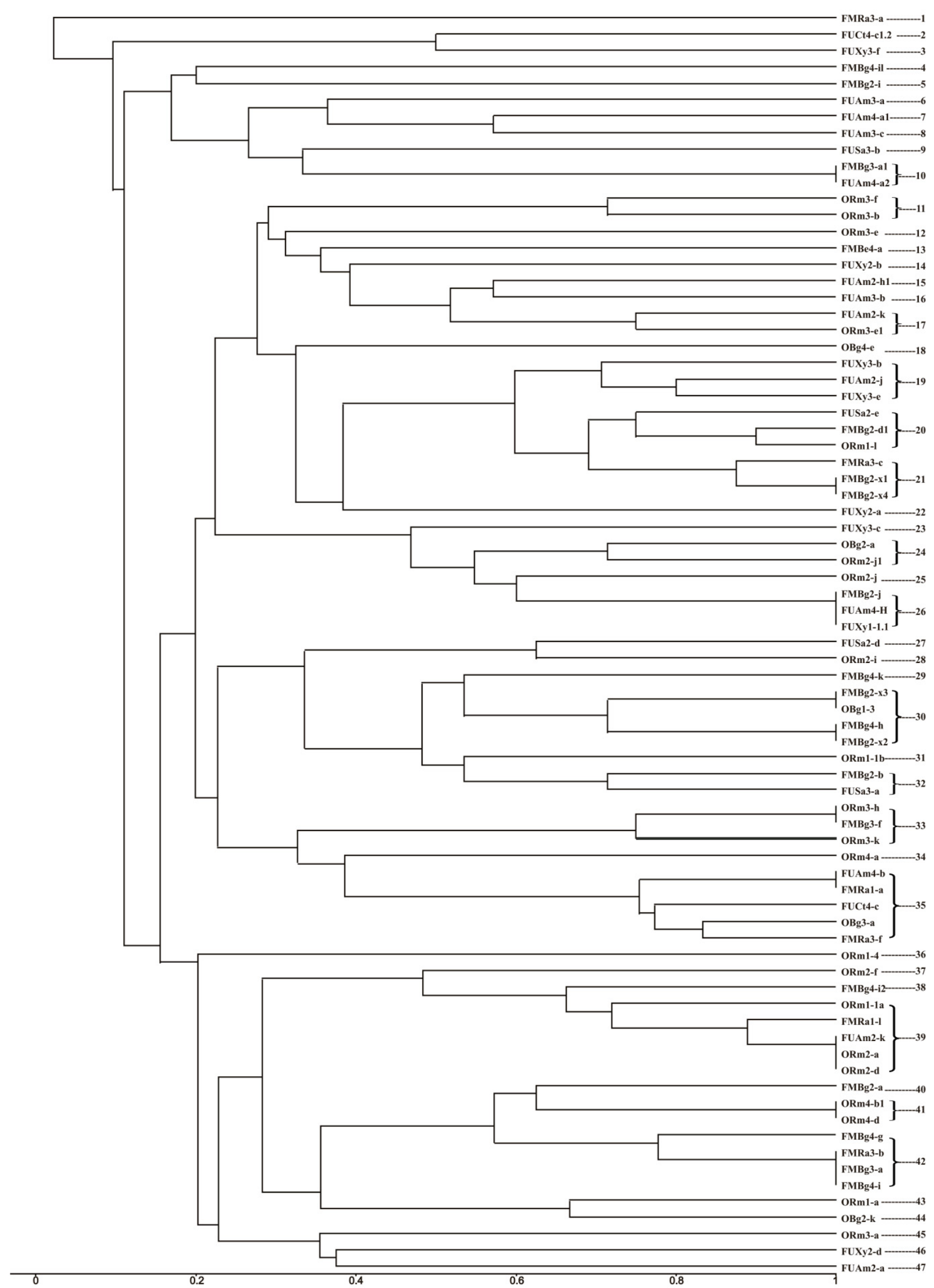

Figure 4. UPGMA dendrogram inferred from ARDRA patterns of Actinomycetes isolated from mangrove rhizosphere. The dendrogram shows the clustering of 77 antibiotic-producing actinomycete isolates generated from amplified ribosomal DNA restriction analysis with restriction endonuclease MSP1, using the UPGMA algorithm and the Jaccard's coefficient. Number 1 to 47 represent the forty seven clusters obtained in the analysis. 


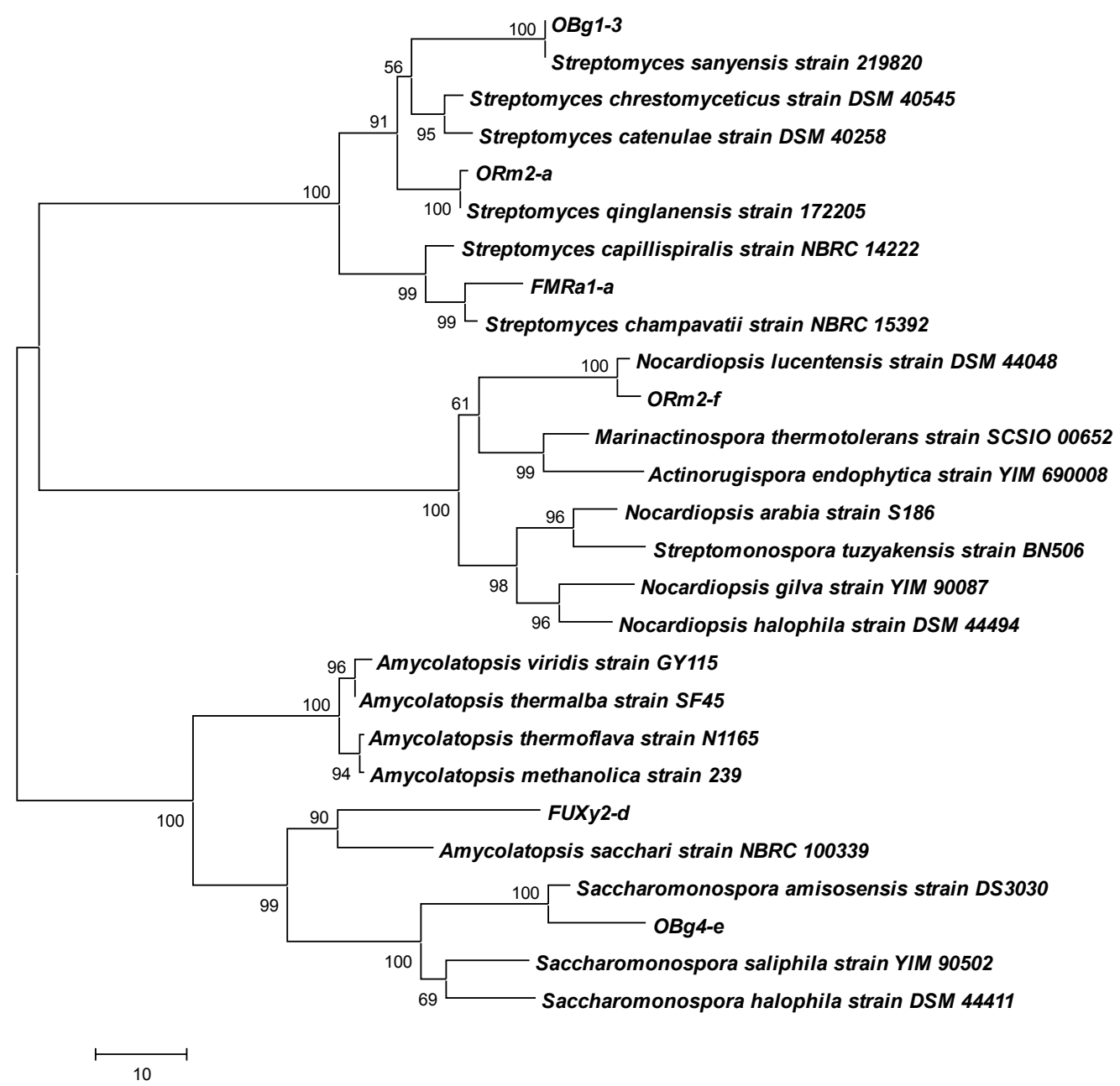

Figure 5. Neighbour-joining phylogenetic tree inferred from $16 \mathrm{~S}$ rRNA gene sequences. The phylogenetic tree shows the phylogenetic relationship of isolates with related genera. Bootstrap values are expressed as percentages of 1000 replications. Bootstrap values, $>50 \%$ are shown at branch points. Score bar represents 1 nucleotide substitution per 100 nucleotides

\section{ACKNOWLEDGEMENTS}

The authors are grateful for the funding from "Research Funds Assistance" of Department of Education and Sports, Government of Gorontalo Province, Indonesia and "Hibah Penelitian Disertasi Doktor" of The Indonesian Ministry of Research and Technology in 2017. We are also thankful to Umar Pasandre as environmentalist of mangrove forest at Torosiaje, Gorontalo, Indonesia.

\section{REFERENCES}

Amrita K, Nitin J, Devi CS. 2012. Novel bioactive compounds from mangrove dirived Actinomycetes. Intl Res J Pharm 3 (2): 25-29

Anupa MP, Sangeetha VS, Praseetha PK, Emelda JJ, Jabaslin EE, Sugunan VS. 2013. Anticancer enzymes from Actinomycetes enhance of tumor induced mice. J Microbiol Biotechnol Res 3 (2): 41-50.

Atlas RM, Bartha R. 1998. Microbial Ecology. Fundamentals and applications. 4th ed. Benjamin/Cummings Publishing Company, Inc. California.

Badri DV, Vivanco JM. 2009. Regulation and function of root exudates. Plant Cell Environ 32: 666-681.
Balagurunathan R, Selvan MM, Karthiresan K. 2010. Bioprospecting of mangrove rhizosphere actinomycetes from Pitchavaram with special reference to antibacterial activity. J Pharm Res 3 (5): 909-911.

Basilio A, Gonzales I, Vicente MF, Gorrochategui J, Cabello A, Gonzales A, Genilloud O. 2003. Patterns of antimicrobial activities from soil actinomycetes isolated under different conditions of $\mathrm{pH}$ and salinity. $\mathrm{J}$ App Microbiol 95 (4): 814-823.

Baskaran R, Vijayakumar R, Mohan PM. 2011. Enrichment method for the isolation of bioactive Actinomycetes from mangrove sediments of Andaman Islands, India. Malays J Microbiol 7 (1): 26-32

Becerril-Espinosa A, Guerra-Rivas G, Ayala-Sanchez N, Soria-Mercado IE. 2012. Antitumor activity of Actinobacteria isolated in marine sediment from Todos Santos Bay, Baja California, Mexico. Rev Biol Mar Oceanogr 47 (2): 317-325.

Berdy J. 2005. Bioactive Microbial Metabolites. J Antibiot 58 (1): 1-26

Chaudhary HS, Soni B, Shrivastava AR, Shrivastava S. 2013. Diversity and Versatility of Actinomycetes and its Role in Antibiotic Production. J App Pharm Sci 3 (1): S83-S94

Das S, Dash HR, Mangwani N, Chakraborty J, Kumari S. 2014. Understanding molecular identification and polyphasic taxonomic approach for genetic relatedness and phylogenetic relationships of microorganisms. J Microbiol Methods 103: 20-100.

Doroghazi JR, Metcalf WW. 2013. Comparative genomics of actinomycetes with a focus on natural product biosynthetic genes. Genomics 14: 611. 
Gayatri P, Muralikrishnan V. 2013. Isolation and characterization of endophytic actinomycetes from mangrove plant for antimicrobial activity. Intl J Curr Microbiol App Sci 2 (11): 78-89.

Govindasamy V, Franco CMM. 2013. Endophytic actinobacteria: diversity and ecology. In: Verma VC, Gange AC. (eds.). Advances in Endophytic Research, Springer, New Delhi.

Hong K, Gao AH, Xie QY, Gao H, Zhuang L, Lin HP, Yu HP, Li J, Yao XS, Goodfellow M, and Ruan JS. 2009. Actinomycetes for marine drug discovery isolated from mangrove soils and plants in China. Mar Drugs 7: 24 - 44

Hu H, Lin HP, Xie Q, Li L, Xie XQ, and Hong K. 2012. Streptomyces qinglanensis sp. nov., isolated from mangrove sedment. Int J Syst Evol Microbiol 62: 596-600

Hunadanamra S, Akaracharanya A, Tanasupawat S. 2013. Characterization and antimicrobial activity of Streptomyces strain from Thai mangrove soils. Intl J Bioassays 2 (5): 775-779

Jose PA, Jebakumar SRD. 2012. Phylogenetic diversity of actinomycetes cultured from coastal multipond solar slattern in Tuticorin, India. Aquat Biosyst 8 (23): 1-9

Khanna M, Solanski R, Lal R. 2011. Selective isolation of rare Actinomycetes producing novel antimicrobial compound. Intl J Adv Biotechnol Res 2 (3): 357-375.

Kumar T, Ray S, Brahmachary RL, Ghose M. 2009. Preliminary GC-MS analysis of compounds present in the root exudates of three mangrove species. Acta Chromatogr J 21 (1). Abstract.

Li TY, Xu F, Yan CL. 2014. Quantitatively analyzing monosaccharides in the root exudates of gray mangrove as its response to cadmium and copper stress. WIT Trans Built Env 156: 265-271

Magarvey NA, Keller JM, Bernan V, Dworkin M, Sherman DH. 2004 Isolation and characterization of novel marine-derived actinomycete taxa rich in bioactive metabolites. Appl Environ Microbiol 70 (12): $7520-7529$

Malek NA, Chowdhury AJK, Zainuddin Z, Abidin ZAZ. 2014. Selective Isolation of Actinomycetes from Mangrove Forest of Pahang, Malaysia. International Conference on Agriculture, Biology and Environmental Sciences (ICABES'14), 8-9 December 2014. [Bali, Indonesian]

Mangamuri UK, Muvva V, Poda S, Kamma S. 2012. Isolation, Identification and Molecular Characterization of Rare Actinomycetes from Mangrove Ecosystem of Nizampatnam. Malays J Microbiol 8 (2): 83-91

Mangamuri UK, Vijayalakshmil M, Poda S. 2014. Exploration of Actinobacteria from Mangrove Ecosystems of Nizampatnam and Coringa for Antimicrobial Compounds and Industrial Enzymes. $\mathrm{Br}$ Biotechnol J 4 (2)

Naikpatil SV, Rathod JL. 2011. Selective isolation and antimicrobia activity of rare Actinomycetes from mangrove sediment of Karwar. J Ecobiotechnol 3 (10): 48-53
Nevine BG, Soraya AS, El-sherif Zeinab M, El-ela Geha A. 2000. J Gen Appl Microbiol 46: 105-111

Nolan RD, Cross T. 1988. Isolation and screening of Actinomycetes, p. 132. In M. Goodfellow, S.T Williams, and M. Mordarski (ed). Actinomycetes in biotechnolgy. Academic Press, San Diego, CA.

Phongsopitanum W, Suwanborirux K, Tanasupawat S. 2014. Identification and antimicrobial activity of Streptomyces strains from Thai mangrove sediment. Thai J Pharm Sci 38 (1): 49-56

Ramirez-Elias MA, Ferrera-Cerrato R, Alarcon A, Almaraz JJ, RamirezValverde G, de-Bashan LE, Ezparza-Garcia FJ. 2014. Identification of culturable microbial functional groups isolated from the rhizosphere of four species of mangrove and either biotechnological potential. Appl Soil Ecol 82: 1-10

Ravikumar S, Fredimoses M, Gnanadesigan M. 2012. Anticancer property of sediment Actinomycetes against MCF-7 and MDA-MB-231 cell lines. Asian Pac J Trop Biomed 2 (2): 92-96.

Ravikumar S, Ibaneson SJ, Uthiraselvam M, Priya SR, Ramu A, Banerjee MB. 2011. Diversity of endophytic Actinomycetes from Karangkadu mangrove ecosystem and its antibacterial potential against bacterial pathogens. J Pharm Res 4 (1): 294-296

Santhi S, Jise AA, Solomon J. 2010. Isolation and characterization of antagonistic actinomycetes from mangrove sediment. Intl J Curr Res 3: $20-23$

Sharma D, Kaur T, Chadha BS, Manhas RK. 2011. Antimicrobial activity of actinomycetes against multidrug resistant Staphylococcus aureus, E. coli and various other pathogens. Trop J Pharm Res 10 (6): 801808.

Suthindhiran K, Kannabiran K. 2010. Diversity and exploration of bioactive marine Actinomycetes in the Bay of Bengal of the Puducherry coast of India. Indian J Microbiol 50 (1): 76-82

Waksman SA. 1950. The Actinomycetes. Their Nature, Occurrence, Activities, and Importance. Waltham, Mass., Chronica Botanica Company USA.

Walker TS, Bais HP, Grotewold E, Vivanco JM. 2003. Root exudation and rhizosphere biology. Plant Physiol 132: 44-51

Xiao J, Wang Y, Luo Y, Xie SJ, Ruan JS, and Xu J. 2009. Streptomyces avicenniae sp. nov., a novel Actinomycetes isolated from the rhizosphere of the mangrove plant Avicennia marina. Intl J Syst Evol Microbiol 59: 2624-2628.

Xu DB, Ye WW, Han Y, Deng ZX, Hong K. 2014. Natural products from Mangrove Actinomycetes. Mar Drugs 12: 2590-2613.

Zotchev SB. 2014. Genomics-Based Insights into the Evolution of Secondary Metabolite Biosynthesis in Actinomycete Bacteria in Evolutionary Biology: Genome Evolution, Speciation, Coevolution and Origin of Life. In: Pontarotti P. (ed). Springer, Switzerland. 